\title{
TESTING THE PROTECTIVE EFFICACY OF MONOVALENT AND BIVALENT ANTIMYCOTIC VACCINES
}

\author{
A. RYBNIKÅR \\ Bioveta, 68323 Ivanovice na Hané \\ Received November 23, 1992
}

\begin{abstract}
Rybnikár, A.: Testing the Protective Efficacy of Monovalent and Bivalent Antimycotic Vaccines. Acta vet., Brno, 62, 1993: 167-172.

Protective efficacy of bivalent vaccines composed of two Trichophyton verrucosum strains, $T$. verrucosum $+T$. mentagrophytes strains and $T$. verrucosum + Microsporum canis strains was approximately equal to, or even lower than, that of the monovalent vaccine containing $T$. verrucosum.

Vaccination, Trichophyton verrucosum, Trichophyton mentagrophytes, Microsporum canis, challenge.
\end{abstract}

Antimycotic vaccines used in veterinary practice in the USSR (TF-130, LTF-130, Mentavak, Kamelvak), Czechoslovakia (vaccine against trichophytosis of cattle, vaccine against trichophytosis of horses, vaccine against trichophytosis of furred animals) and in Poland (Trichovac, Bovitrichovac) have one feature in common: each of them contains only one vaccination strain. We thought it of interest to find whether the potency of a monovalent vaccine could be increased by addition of further dermatophyte strains.

The experiments were carried out with the following vaccines:

(a) commercial freeze-dried vaccine against bovine trichophytosis (manufactured by Bioveta, Ivanovice na Hané) the active ingredient of which is $T$. verrucosum strain CCM 8165;

(b) experimental monovalent vaccines containing $T$. verrucosum, $T$. mentagrophytes and $M$. canis strains; and

(c) bivalent vaccines consisting of the afore-mentioned strains.

\section{Materials and Methods}

The experimental animals were one-month old calves of the Bohemian pied breed from a herd without a history of trichophytosis. They were vaccinated with freeze-dried living monovalent or bivalent vaccine containing sporulating cultures grown on agar nutrient media. Trichophyton verrucosum CCM 8165 and CCM 8167 strains were originally isolated from cattle, Trichophyton mentagrophytes strain 1069 from a guinea-pig and Microsporum canis strain 6602 from a dog. The vaccines were injected i.m. into the gluteal muscle on two occasions 12 days apart. Twentyeight days after revaccination the vaccinated calves and non-vaccinated controls were challenged with a sporulating culture of $T$. verrucosum isolated from a bovine deep mycotic focus. The challenge culture was inoculated epicutaneously at the rate of 10 million conidia per animal into a $10 \times 10 \mathrm{~cm}$ clipped and gently scarified area of the right flank. The animals were then observed for the presence of clinical dermal changes at the site of inoculation of the challenge culture for the following 32 days. Positive clinical findings were examined by culture and with a microscope (Rybunikár 1992). 


\section{Results}

Calves vaccinated with $T$. verrucosum strains CCM 8165 and CCM 8167 showed good protection against infection with the homologous species (Table 1). After being challenged, the animals vaccinated with monovalent $T$. verrucosum vaccines showed either no clinical signs of trichophytosis or developed only slight dermal changes of short duration. At the end of the experiment all these animals were clinically negative. In the groups of calves given the vaccine composed of the two $T$. verrucosum strains, trichophytosis persisted throughout the observation period in 1 out of 7 animals. Mycotic changes were less pronounced in a calf vaccinated with higher doses of the mycotic antigen.

All calves immunized with the bivalent $T$. verrucosum $+T$. mentagrophytes vaccine (Table 2) showed variously extensive mycotic changes that could be observed up to 17 to 26 days after challenge. At the end of the experiment all these animals were clinically negative. In 4 out of 9 animals vaccinated with

Table 1

Tests of the protective efficacy of vaccines prepared from $T$. verrucosum CCM 8165 and $T$. verrucosum CCM 8167 strains

Vaccination strain Vaccination dose

(CFU per calf)

T. verrucosum

$(2 \times 10$ million)

T. verrucosum

CCM 8167

$(2 \times 10$ million $)$

T. verrucosum

CCM 8165

$(2 \times 5$ million)

T. verrucosum

CCM 8167

( $2 \times 5$ million)

$T$. verrucosum

CCM 8165

$(2 \times 10$ million $)$

T. verrucosum

CCM 8167

$(2 \times 10$ million $)$

Controls

Calf. No.
Dermal mycotic changes after challenge with $T$. verrucosum strain, days after challenge

$12 \quad 15$

\begin{tabular}{|c|c|c|c|c|c|c|}
\hline 007 & \pm & \pm & - & - & - & - \\
\hline 012 & $\bar{t}$ & $\bar{t}$ & \pm & - & - & - \\
\hline 020 & + & + & $\bar{t}$ & + & - & - \\
\hline 026 & \pm & \pm & - & - & - & - \\
\hline 472 & $=$ & $=$ & - & - & - & - \\
\hline 473 & - & - & - & - & - & - \\
\hline 775 & - & - & - & - & - & - \\
\hline
\end{tabular}

19

\begin{tabular}{|c|c|c|c|c|c|c|}
\hline 007 & \pm & \pm & - & - & - & - \\
\hline 012 & $\bar{t}$ & $\bar{t}$ & \pm & - & - & - \\
\hline 020 & + & + & $\bar{t}$ & + & - & - \\
\hline 026 & \pm & \pm & - & - & - & - \\
\hline 472 & $=$ & $=$ & - & - & - & - \\
\hline 473 & - & - & - & - & - & - \\
\hline 775 & - & - & - & - & - & - \\
\hline
\end{tabular}

23

\begin{tabular}{|c|c|c|c|c|c|c|}
\hline 007 & \pm & \pm & - & - & - & - \\
\hline 012 & $\bar{t}$ & $\bar{t}$ & \pm & - & - & - \\
\hline 020 & + & + & $\bar{t}$ & + & - & - \\
\hline 026 & \pm & \pm & - & - & - & - \\
\hline 472 & $=$ & $=$ & - & - & - & - \\
\hline 473 & - & - & - & - & - & - \\
\hline 775 & - & - & - & - & - & - \\
\hline
\end{tabular}

28
32

\begin{tabular}{|c|c|c|c|c|c|c|}
\hline 007 & \pm & \pm & - & - & - & - \\
\hline 012 & $\bar{t}$ & $\bar{t}$ & \pm & - & - & - \\
\hline 020 & + & + & $\bar{t}$ & + & - & - \\
\hline 026 & \pm & \pm & - & - & - & - \\
\hline 472 & $=$ & $=$ & - & - & - & - \\
\hline 473 & - & - & - & - & - & - \\
\hline 775 & - & - & - & - & - & - \\
\hline
\end{tabular}

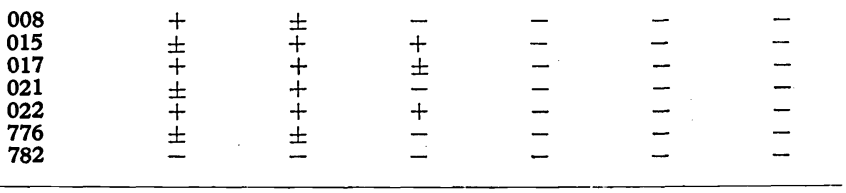

006

013

013

685

779

780

781

$\begin{array}{lr}+ & + \\ + & \pm \\ + & + \\ + & + \\ \pm & \pm \\ \pm & +\end{array}$

+
+
+
+
+
+
\pm

$\frac{ \pm}{+}$
+
+

$\bar{z}$
$+\bar{z}$
$\bar{z}$

$\begin{array}{rr}\bar{z} & \overline{-} \\ +\bar{t} & +\overline{+} \\ \bar{z} & \overline{-} \\ - & -\end{array}$

\section{9}

014

016

019

683

684

778

\pm
$\overline{-}$
\pm
\pm

-
$\bar{z}$
$\bar{z}$

$\begin{array}{rr}+t & ++t \\ \pm & +t \\ \pm & + \\ + & +t \\ + & ++t \\ + & ++t \\ \pm & +t\end{array}$

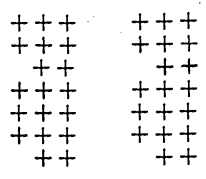


T. mentagrophytes vaccine, trichophytic foci persisted throughout the observation period.

Calves vaccinated with $M$. canis vaccine (Table 3 ) developed, after challenge, trichophytosis of the same extent as non-vaccinated controls. At the site of inoculation of the challenge culture, individual or confluent mycotic foci painful to the touch were recorded. In most cases even the deep layers of the skin were affected. The potency of the bivalent $T$. verrucosum $+M$. canis vaccine proved very gocd, being comparable to that of the monovalent $T$. verrucosum vaccine.

The results of examination by culture and of microscopic examination were in keeping with the clinical findings. In clinically affected animals the challenge $T$. verrucosum strain was demonstrated upon laboratory examination.

\section{Discussion}

Experiments with vaccination of animals with living antigens containing two dermatophyte strains have been described by Petrovich et al. (1972). In his experiments all three calves immunized with a vaccine containing $T$. verrucosum

Table 2

Tets of protective efficacy of vaccines prepared from $T$. verrucosum CCM 8165 and $T$. mentagrophytes No. 1069 strains

Vaccination strain

Vaccination dose

(CFU per calf)

242

T. verrucosum

CCM 8165

$(2 \times 10$ million $)$

T. mentagrophytes

No. 1069

$(2 \times 6$ million $)$

T. verrucosum

CCM 8165

$(2 \times 10$ million $)$

T. mentagrophytes

No. 1069

( $2 \times 6$ million)
Calf

No.
Dermal mycotic changes after challenge with $T$. verrucosum strain, days after challenge

17

21

26

32 
Table 3

Tests of protective efficacy of vaccines prepared from T. verrucosum CCM 8165 and $M$. canis No. 6602 strains

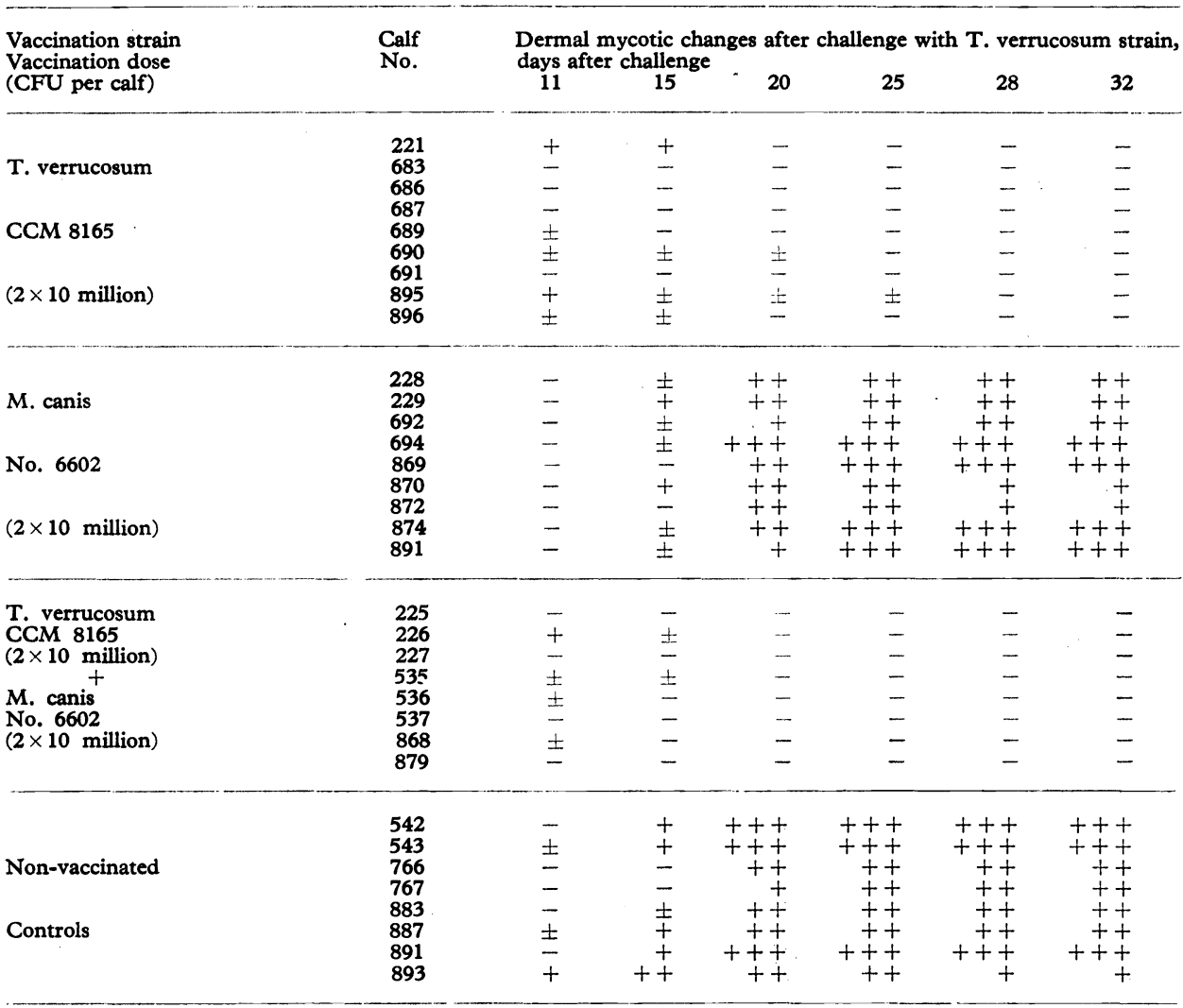

Explanation to Tables 1 to 3

CFU = colony-forming units.

- No dermal mycotic changes.

\pm Minute dermal changes (scales, papillae).

+ Solitary mycotic foci.

++ Mycotic foci covering more than a $1 / 4$ of the inoculated area.

+++ Mycotic foci covering more than half of the inoculated area.

and T. mentagrophytes strains developed trichophytosis after challenge with the $T$. verrucosum strain. The use of the monovalent $T$. verrucosum vaccine conferred full protection against experimental infection with the homologous strain. Calves vaccinated with $T$. mentagrophytes vaccine were not resistant to infection with $T$. verrucosum culture. Although these results suggested certain relationships, they cannot be taken as conclusive evidence considering the small numbers of experimental calves ( 2 to 3 animals) in each group.

Wawrzkiewicz et al. (1991), on the other hand, reported that both monovalent ( $T$. verrucosum) and bivalent ( $T$. verrucosum $+T$. mentagrophytes) vaccine conferred a reliable degree of protection against experimental infection with virulent strains of the two dermatophytes.

In our challenge experiments on 102 calves the bivalent vaccines were based on the vaccination $T$. verrucosum strain CCM 8165. Its protective efficacy against 
experimental infection with $T$. verrucosum proved very good. The vaccine consisting of two $T$. verrucosum strains was as efficacious as the monovalent $T$. verrucosum vaccine in 6 out of 7 animals. One calf each of the two groups vaccinated with these bivalent vaccines reacted to challenge with mycotic changes that persisted throughout the observation period.

The protection of calves vaccinated with the $T$. mentagrophytes strain against infection with the heterologous $T$. verrucosum strain was lower; 4 out of 9 calves exhibited trichophytic foci up to the end of the experiment. This is in keeping with the results of our previous study (Rybnikár 1992 ) on postvaccination cross-immunity. The bivalent vaccine consisting of $T$. verrucosum $+T$. mentagrophytes strains conferred a satisfactory degree of protection. However, mycotic changes in response to challenge were observed in all calves of this group and were more conspicuous and persisted for a longer period of time than those seen in calves vaccinated with the commercial monovalent $T$. verrucosum vaccine.

The monovalent vaccine containing $M$. canis proved entirely inefficacious. In this case no cross-immunity against the challenge $T$. verrucosum strain was observed. The protective effect of the $T$. verrucosum $+M$. canis vaccine, on the other hand, was considerable, being comparable to that conferred by $T$. verrucosum vaccine.

The results of our experiments suggest the involvement, to a certain extent, of phenomena described as antigen competition. These phenomena come into play when several antigens are applied simultaneously or closely one after another (Nouza and John 1987). These antigens sometimes potentiate one another; more frequently, however, the response to several antigens is below that one might expect if they were administered separately. Negative effects on the development of postvaccination immunity against trichophytosis in consequence of concurrent administratoin of vaccine $T F-130$ and vaccine against mouth-and-foot disease have been reported by Ruchljada et al. (1973). In our experiments the protective efficacy of bivalent vaccines was approximately equal to, or even relatively lower than, that of one member of the pair of the monovalent vaccines. Although the differences were not great, it seems possible to conclude that negative effects on the protective efficacy came into operation particularly in the groups vaccinated with strains of presumably similar antigenic structure $(T$. verrucosum $+T$. verrucosum, $T$. verrucosum $+T$. mentagrophytes). The efficacy of bivalent vaccines containing strains of more differing antigenic structure ( $T$. verrucosum $+M$. canis) was not reduced as against that of the monovalent vaccine.

The results reported here are of value particularly by showing that the use of two dermatohyte strains in an attempt to extend the antigenic structure of a vaccine may not increase its protective efficacy as against the monovalent vaccine and may even result in an opposite effect.

\section{Ověřování protektivní účinnosti monovalentních a bivalentních anti- mykotických vakcín}

Protektivní účinnost bivalentních vakcín, složených ze dvou kmenů Trichophyton verrucosum, $\mathrm{z}$ kmenů $T$. verrucosum $+T$. mentagrophytes a $\mathrm{z}$ kmenů $T$. verrucosum + Microsporum canis, byla přibližně stejná nebo i nižší než u monovalentní vakcíny, obsahující $T$. verrucosum. 


\section{Проверка защитного действия одновапетных и двүхвапентных антимикотических вакцин}

Защитное воздействие Авухвалентных вакцин, состоящих из двух штаммов Trichophyton verrucosum и из штаммов T. verrucosum + T. mentagrophytes было ниже в сопоставлении с одновалентной вакциной, содержащей T. verrucosum. После иммүнизации телят вакциной, подготовленной из культүр $T$. verrucosum + Microsporum canis, пониженного профилактического эффекта по сравнению с группой, вакцинированной штаммом $T$. verrucosum, не наблюдали.

\section{References}

NOUZA, K. - JOHN, C.: Imunologie zdraví a nemoci. Avicenum Praha, 1987

PETROVICH, S. V.-MAKARCHENKO, A. V.-KUZMIN, I. V.: Izučenie perekrestnogo immuniteta $u$ teljat $k$ vozbuditeljam Trichophyton faviforme $i$ Trichophyton gypseum. Bjul. Vses. ord. Lenina inst. eksper. vet., 12, 1972: 20-22

RUCHLJADA, V. V.-NIKOLAEV, S. M.- SUTJUK, V. K.: Effektivnost' specifičeskoj profilaktiki trichofitii. Veterinarija (Moskva), 1973, (6): 54-56

RYBNIKÅ̌, A.: Cross-immunity in calves after vaccination against trichophytosis. Acta vet. Brno, 61, 1992: 189-194

WAWRZKIEWICZ, J.-WAWRZKIEWICZ, K.-SADZIKOWSKI, Z.: Monowalentna i skojarzona szczepionka inaktywowana w profilaktyce trychofitozy lisów hodowlanych. Med. weter., 47, 1991: $317-320$ 